\title{
Research Quality Matters
}

\author{
Ray J. Paul \\ Department of Information Systems and Computing, Brunel University, West London, United Kingdom
}

\begin{abstract}
This paper discusses issues that arise when considering what is meant by the expression 'research quality' in universities. Popular measures of research quality are often based on determining the quality of a published journal paper, or of using these to publish journal league tables based on the assumption that the journal quality represents the quality of the papers published by the journal. This paper argues that measuring the quality of a research publication cannot be done. Therefore a journal league table also has no meaning. The issue of the use of the surrogate of Journal League Tables is used to exemplify some of the issues that need to be addressed by the community to avoid the inequality quality trap. A number of suggestions are made to establish a sounder basis for dealing with real quality properly. This is not an information systems crisis paper or similar nonsense, but one possible positive way forward.
\end{abstract}

Keywords: information systems, quality, publishing, good practice

\section{Information Systems Publications}

Dissemination is the bedrock of academic research, for without it, the research undertaken may as well not have been undertaken. Since publication is the main observable output of academic endeavour, a thinking-free approach to the question concerning quality, value for money, etc popularly points to the measuring of the quality of a research publication as though this could be meaningful in some way. I have argued against the absurdity of such a view, and will doubtless need to continue to do so (see Paul's papers [1] to [17] for comments on these matters as well as anything to do with change). Without attempting to be comprehensively damning about the issue, I observe

- We have no criteria for evaluating the quality of a paper other than peer review.

- Peer review is notoriously conservative.
- Research progress comes from disestablishing the accepted beliefs of the research community, not by merely trying to show that the accepted beliefs are in some sense "correct".

- The impact of any research result has a variable life span, sometimes immediate, sometimes with a very long fuse.

- What is believed to be good or bad quality is a dependency of too many variables: state of the world, fashionable research directions, reputation of the researcher, what people want to believe etc.

One of the reasons for this conundrum is that paper quality gets confused with peer review. Obviously, quality journals review papers for publication and the method used is peer review by referees. But such peer review is not to measure the quality of papers, but whether the paper meets some (imaginary?) standard for that journal. This is not the same as measuring the paper's quality, but merely whether or not a threshold has been reached. I have sat on two panels/sub-panels for the U.K. Government's Reasearch Assessment Exercise (RAE) in 2001 and 2008. The RAE is an attempt to measure the quality of research in universities in order to allocate research resources. The RAE panels, and future such exercises have deliberately resisted using league tables since there is no confidence that they really tell you much. For example, a recent high flying journal had many of its papers graded low because the journal had changed policy and wanted papers with research results, but not research methods. No research methods, no research quality, was the verdict.

Given these comments, you might wonder if research publications have any value at all. Our knowledge, tenuous as it is, is enhanced by an 
open debate amongst interested parties, from which one might expect a gradual improvement in understanding (cf On Giant's Shoulders). Such a debate is to my mind indivisible, and major contributions are, I suggest, less discernible in the general debating hubbub than some would like to assume.

To summarise, research publication is essential to research progress, but associating quality value (of a positive kind) can only be pretence.

\section{Journal League Tables}

Measuring the research quality of a research publication, whilst impossible, would be tedious if the method of evaluation is to read the paper, would it not? So, would it not be desirable to find an easier-to-use surrogate? It is currently considered that one can assume that the place of publication has some two-way reflected glory with the papers published. If so, it would then be a good idea to believe that you can ascertain the quality of a paper just from the place of publication, would it not? Then, all you have to do is produce a ranking of the journals and hey presto, now you know the quality of the paper. All very conveniently easy, not requiring much intellectual effort and easily regulated. And nonsense. And you can use the league tables to put pressure on employees to produce "better" research by mandating which journals they should publish in. In this way, the issue of research quality is entirely the responsibility of the individual - publish in these journals at such and such a rate or you have contractually failed.

But what if the recommended journals are the same for so many institutions that the combined desired research output of these institutions exceeds the combined capacities of the journals selected? Well, that is what competition is all about, supposedly good for you! That would ensure that research operators, people with an ability to judge how to write an acceptable paper from a peer review point of view, rise to the top. Well, you never know, they might coincidentally have something worth reporting on!

I hope this makes quite clear my view about journal league tables. But maybe I am being too critical. People like league tables, a sense of winning and losing. I am one of the editors of the European Journal of Information Systems (EJIS). I have no regard for league tables, but given the fact that they exist, I want to be high up the table, preferably number one. And I enjoy real games. So, let us play games with league tables to see how meaningful they might or might not be.

\section{Fun and Games: Measuring Measures}

\subsection{AIS league table}

Whose table shall we start with? How about the AIS MIS Journal Rankings that should be respectable enough. I shall restrict my fun and games to the basket of eight journals recommended by AIS's Senior Scholars. This gives the league table shown in Table 1.

\begin{tabular}{|c||c|c|}
\hline Journal & Position in AIS table & Relative Position \\
\hline \hline MISQ & 1 & 1 \\
\hline ISR & 2 & 2 \\
\hline JMIS & 5 & 3 \\
\hline EJIS & 11 & 4 \\
\hline JAIS & 26 & 5 \\
\hline ISJ & 32 & 6 \\
\hline JSIS & 46 & 7 \\
\hline JIT & 78 & 8 \\
\hline
\end{tabular}

Table 1. AIS League Table.

So EJIS is the fourth, the first amongst nonNorth American journals. Biased? OK, let us look at the flavour of the moment, Impact Factors, shown in Table 2.

\subsection{Impact factors}

\begin{tabular}{|c||c|c|}
\hline Journal & Impact Factor 2008 & Relative Position \\
\hline \hline MISQ & 5.183 & 1 \\
\hline JMIS & 2.375 & 2 \\
\hline ISR & 2.358 & 3 \\
\hline JIT & 2.261 & 4 \\
\hline JAIS & 1.966 & 5 \\
\hline ISJ & 1.484 & 6 \\
\hline JSIS & 1.202 & 7 \\
\hline EJIS & 1.836 & 8 \\
\hline
\end{tabular}

Table 2. The 2008 Impact Factors. 
What does this show? EJIS is the last. No, the table shows the need to translate impact factor movements over time, and not just take a snapshot view. The highlights of the 2008 Impact Factors for IS journals show:

1. MISQ, down slightly at 5.183 , number one IS journal, number 3 amongst all management journals.

2. ISR, crashing down at 2.261 from previous high values.

3. EJIS eighth at $1.202,28^{\text {th }}$ amongst all management journals.

4. Now some observations:

- EJIS made a gain in Impact Factor of over 0.4 since 2007.

- EJIS was one of the top two journals with more papers listed in the $2008 \mathrm{RAE}$ than any other IS journals.

- EJIS's Impact Factor is distorted by the following deliberate policy of the EJIS editors.

a) EJIS was a four issues a year journal four or five years ago, publishing about 24 papers a year or about 300 pages.

b) It was decided to use its reputation to go for a larger market by switching to six issues a year and increasing pagination per issue. EJIS now publishes about 50 papers per year in 700 pages over 6 issues.

c) The way the Impact Factor is counted (citations divided by number of papers) means that if the number of papers goes up, the Impact Factor goes down. And vice versa. So EJIS went down for 3 years (there was a 5 issue interim year as well), but is now going up.

- EJIS is substantively advancing and is beginning to be seen as the journal of first choice to publish in amongst most authors (hence its popularity in RAE 2008).

So, there you have it, EJIS is top 28, and the most published in, and in the steady state, at least the third or even the second ranked IS journal.
If we take MISQ and ISR as the 'quality' journals, the 3 to 4 year publication turnaround time will not reflect quality, merely who has conducted research in these journals between 1997 and 2005. Let us look at another ranking criterion.

\subsection{Number of papers published}

Where would authors like to publish? In quality journals. So wouldn't the number of papers published in a journal each year indicate relative quality? See Table 3.

\begin{tabular}{|c||c|c|}
\hline Journal & $\begin{array}{c}\text { Papers } \\
\text { Published } \\
\text { (PP) }\end{array}$ & $\begin{array}{c}\text { Relative } \\
\text { Position }\end{array}$ \\
\hline \hline EJIS & 87 & 1 \\
\hline JMIS & 84 & 2 \\
\hline MISQ & 82 & 3 \\
\hline JAIS & 67 & 4 \\
\hline ISR & 55 & 5 \\
\hline JIT & 54 & 6 \\
\hline ISJ & 51 & 7 \\
\hline JSIS & 32 & 8 \\
\hline
\end{tabular}

Table 3. Number of papers published in last 2 years.

That's a good result for EJIS! No? You disagree, size isn't everything. But EJIS's acceptance rate is now at an all time low of 8-9\% of submissions, and is the same for special issues as for general submissions. EJIS has 33 Associate Editors and Seniors, mostly well known, but all active and enthusiastic. The quality of published papers is obviously high.

If you don't like this argument, let us try popularity combined with impact, to give some impression of the 'force' of the journal.

\subsection{Popularity and impact factors}

The combined papers published times impact factor gives a measure of strength of impact or force (see Table 4).

But we have to be careful. Normalisation has taken place, so small decimal points can cause interestingly large differences. So I show positions relative to other major positions. This is an example of one combination. Now let us look at some more general combinations. 


\begin{tabular}{|c||c|c|c|c|}
\hline Journal & $\begin{array}{c}\text { Impact } \\
\text { Factor } \\
(\mathbf{I F})\end{array}$ & $\begin{array}{c}\text { Papers } \\
\text { Published } \\
(\mathbf{P P})\end{array}$ & $\mathbf{I F} \times \mathbf{P P}$ & $\begin{array}{c}\text { Relative } \\
\text { position }\end{array}$ \\
\hline \hline MISQ & 5.183 & 82 & 425 & 1 \\
\hline JMIS & 2.358 & 84 & 198 & 2 \\
\hline ISJ & 1.660 & 51 & 85 & $=3$ \\
\hline JIT & 1.966 & 54 & 106 & $=3$ \\
\hline ISR & 2.261 & 55 & 124 & $=3$ \\
\hline EJIS & 1.202 & 87 & 105 & $=3$ \\
\hline JAIS & 1.836 & 67 & 122 & $=3$ \\
\hline JAIS & 1.484 & 32 & 48 & 8 \\
\hline
\end{tabular}

Table 4. Number of papers published in last 2 years, times impact factor.

\subsection{The fiddling-with-violins (cf Nero) league table}

But why be so conservative? Many league tables are weighted combinations of other league tables (see Table 5).

To get EJIS to be number one, all that has to be done is putting a high enough weight on the measure of performance it is best in. So we can see that most journals can be number one in a league table built to seek that outcome.

\section{Quality Matters}

What has the above got to do with quality? Nothing, of course, although many would like to pretend it does. Why? The measured person knows exactly what will and what will not get him/her promotion in the system; the measurer person has a relatively easy task of recording quality using just the journal's league table ranking.

If one is concerned with quality, then the following advice by, Paul $[15,16]$ is worth repeating.

As Paul mentioned before in the European Journal of Information Systems [15], you could do worse than making sure your paper would provide 'obvious' answers to the four questions below. In fact, very few published papers meet all four questions obviously. But they would be better papers if they did.

Assuming the paper is an appropriate paper for the journal it is being submitted to, then:

1. What story are you trying to tell the reader? One story, note, not many. There may be two or three major points to the story, but much more than that confuses readers. A story written for the reader can be understood in 10 years time by the author if they need to revisit the paper. A story written for the writer (the majority published) will leave the authors as perplexed in 10 years time as readers are now.

2. What will the reader know after reading your story that they did not know before reading the story?

The whole point of the paper one presumes.

3. Why should anyone believe you?

This is the downfall of many papers, but if not believable, then that is the end of the paper.

4. Why should anyone care about the story being told?

What value will the reader attach to the point

\begin{tabular}{|c||c|c|c|c|c|c|c|}
\hline Journal & $\begin{array}{c}\text { AIS } \\
\text { league } \\
\text { table }\end{array}$ & $\begin{array}{c}\text { Impact } \\
\text { Factor } \\
(\mathbf{I F})\end{array}$ & $\begin{array}{c}\text { Papers } \\
\text { Published } \\
(\mathbf{P P})\end{array}$ & $\mathbf{I F} \times \mathbf{P P}$ & RAE papers & Ray's rank & Ray's wtd rank \\
\hline \hline EJIS & 4 & 8 & 1 & 3 & 2 & $=3(18)$ & $1(37)$ \\
\hline JMIS & 3 & 2 & 2 & 2 & 7 & $2(16)$ & $2(54)$ \\
\hline MISQ & 1 & 1 & 3 & 1 & 6 & $1(12)$ & $3(69)$ \\
\hline JAIS & 5 & 5 & 4 & 3 & 8 & $6(25)$ & $4(101)$ \\
\hline ISR & 2 & 3 & 5 & 3 & 5 & $=3(18)$ & $5(113)$ \\
\hline JIT & 8 & 4 & 6 & 3 & 1 & $5(22)$ & $6(136)$ \\
\hline ISJ & 6 & 6 & 7 & 3 & 4 & $7(26)$ & $7(163)$ \\
\hline JSIS & 7 & 7 & 8 & 8 & 3 & $8(32)$ & $8(184)$ \\
\hline
\end{tabular}

Table 5. Combined Table of Tables. 
of the story? If none, you will find that reviewers tend to disguise this problem under the rubric 'significance of the contribution'.

5. What is the essence of your paper in one sentence?

I know I said four questions, but the fifth question has nothing to do with whether your paper is published or not. Answering this question readily enables readers to attach the idea to you, the author, and hence is likely to push your citation index up and enhance your reputation.

6. What motivated your research and the paper you have written?

Again, I know I said four questions, but the sixth question may have nothing to do with whether your paper is published or not. Putting this information in your paper is likely to make the paper more interesting, and therefore it might be more widely read than otherwise.

So it should be clear from the above that if we would like what is published in our journals to change, then we, the research community, have to change how we go about our business. There is no one else to do it. I look forward to a flood of well-written publishable papers submitted to EJIS in the near future.

\section{Paul's Seven Success Factors for I.S.}

But this is all rather narrow, a part of the I.S. communities activities. There is talk of crisis in I.S. which I have no time for. I see a positive future for I.S., driven by the continuing saga of big system 'disappointments', which shows the huge need for help from us. What should we do? I think I have hinted at all the necessities for success in this short study of journal league tables. So let me present them, Paul's Seven Success Factors for I.S. Please note that this for me is not a list to choose from, success depends on all seven factors being addressed, since they all interact with each other.

\section{Integrity}

If we cannot be trusted, we shall not be used. Sometimes we have to say unpalatable things, but this is necessary for long-term trust. We should constantly ask ourselves concerning our activities "What good is it?".

\section{Dissemination}

Research quite simply may as well as not have occurred if the benefits are not disseminated. All researchers should ensure that their work is in the public domain (but see 6 in particular).

\section{Experience}

How can we research into I.S. unless we have considerable experience of practice, which we continuously maintain? Research into theory may be fun, but if the theory is of a fantasia, it hardly enhances our integrity.

\section{Confidence}

First, you should believe in yourself. If you don't, why should anyone else? But what if you are not self-confident? Talleyrand, Napoleon's and the Restoration's Foreign Minister was a noted self-confident man. When asked by a brave soul why he had such self-confidence, he is reported to have said something like: "When I examine myself, I worry. When I compare, I am reassured!"

We should be confident about I.S. The latter is a new subject with a poor body of knowledge and many difficulties in practice. Great, lots of opportunities to make major contributions early on, as in other subjects when they started up. Who wants to research into a mature academic discipline, with an excess of well formed knowledge and only room to make largely insignificant contributions. Other new subjects, management etc? Puffs of wind, 2 by 2 matrices, the 4 or 5 P's and other rigorous trivia. My work in I.S. is potentially ground breaking, fun, and if successful, would help society. What more could I want?

\section{Quality}

Quality could be greater in any organisation if Quality Assurance and its related paraphernalia were not applied, because the time saved would be made available. Quality is not about benchmarks and standards, which assume a 'stopping' point, it is about improving what you do all the time - forever!

\section{Simple}

I firmly believe that if you understand something well, you can express it simply, and if you cannot express it simply, you do not understand it well. So, for example, after 
20 years of vain attempts, I now have a definition of I.S. which succinctly captures the essence of what it is, is easily explained to the uninitiated and is only 7 words:

\section{I.S. is I.T. in Use}

In Use implies users, so it's the combination of I.T. and users in Use that implies a time dimension, so an I.S. has a time associated with it. Hence the combination of users using I.T. plus any ad hoc decisions gives the I.S at that point in time. Can you do better?

\section{Determination}

In my experience, whilst academics can be tenacious about their pet ideas, when it comes to matters of the world, they tend to bore easily if the argument is sustained. So if we want to establish I.S. we need a concerted community determination to make it happen. Then it will. If you cannot be bothered to defend your subject, don't be surprised if your disciplinary home disappears about you.

\section{Conclusions}

This paper shows that almost any journal can be top of a league table using the current methods of league table construction. If anyone believes in such tables, they are a victim of their model and should be kept away from management.

\section{References}

[1] R. J. PAUL, Time, changes and paradoxes. European Journal of Information Systems, 12, p. 77 (2003).

[2] R. J. PAUL, More changes and responses. European Journal of Information Systems, 12, p. 167 (2003).

[3] R. J. PAUL, Time, experience and change. European Journal of Information Systems, 13 (2004), pp. 93-94.

[4] R. J. PAUL, Time, change and beliefs. European Journal of Information Systems, 13, p. 165 (2004).

[5] R. J. PAUL Time, change and EJIS. European Journal of Information Systems, 13 (2004), pp. 245-246.

[6] R. J. PAUL, Editor's view: an opportunity for editors of IS journals to relate their experiences and offer advice. The Editorial View of Ray J Paul. First in a series. European Journal of Information Systems, 14 (2005), pp. 207-212.
[7] R. J. PAUL, Changing issues: sixes and specials. European Journal of Information Systems, 15 (2006), pp. 1-3.

[8] R. J. PAUL, Views, change and changing views. European Journal of Information Systems, 15 (2006), pp. 239-240.

[9] R. J. PAUL, Making the changes. European Journal of Information Systems, 15 (2006), pp. 525-526.

[10] R. J. PAUL, Change strikes back. European Journal of Information Systems, 16 (2007), pp. 1-2.

[11] R. J. PAUL, Changes to information systems: time to change. European Journal of Information Systems, 16 (2007), pp. 193-195.

[12] R. J. PAUL, Changing the challenge: To challenge makes you larger and being challenged makes you small. European Journal of Information Systems, 16 (2007), pp. 299-302.

[13] R. J. PAUL, Changeover and celebrating change: 20 reasons for celebrating 20 years. European Journal of Information Systems, 16 (2007), pp. 525-526.

[14] R. J. PAUL, Time for a change. European Journal of Information Systems, 16 (2007), pp. 667-668.

[15] R. J. PAUL, What is published in our journals cannot change unless we do. European Journal of Information Systems, 18 (2009), pp. 189-191.

[16] R. J. PAUL, Editorial. Journal of Computing and Information Technology, 18, pp. i-iv (2010).

[17] R. J. PAUL, Loose change. European Journal of Information Systems 19 (2010), pp. 379-381.

Received: June, 2010 Accepted: November, 2010

Contact address:

Ray J. Paul Department of Information Systems and Computing Brunel University West London UB8 3PH United Kingdom e-mail: ray.paul@brunel.ac.uk

RAY J. PAUL, Emeritus Professor at Brunel University and Visiting Professor at the London School of Economics, both in the U.K., first attended ITI in 1988. He more or less fell instantly in love with Cavtat, the conference and another conference delegate. Since 1988 Ray has attended well over half the conferences to date, including some when ITI was held in Pula. Ray has also been a member of CIT's Editorial Board since it started, and this will be the fifth or sixth CIT special issue that Ray will have edited. 